\title{
Canopy Gas Exchange and Water Use Efficiency of 'Empire' Apple in Response to Particle Film, Irrigation, and Microclimatic Factors
}

\author{
D. Michael Glenn ${ }^{1}$ \\ United States Department of Agriculture, Agricultural Research Service, Appalachian Fruit Research \\ Station, 2217 Wiltshire Road, Kearneysville, WV 25430-2771
}

\begin{abstract}
ADDITIONAL INDEX WORDS. kaolin, Surround, vapor pressure deficit, photosynthetically active radiation, leaf area ratio, Malus $\times$ domestica

ABstract. This study examined the interaction between a reflective particle film and water use efficiency (WUE) response of irrigated and non-irrigated apple trees (Malus $\times$ domestica) over a wide range of environmental conditions. The objectives were to measure isotopic discrimination $\left(\Delta^{13} \mathrm{C}\right.$ and $\left.\delta^{18} \mathrm{O}\right)$, specific gas exchange, and WUE response of 'Empire' apple treated with a reflective particle film (PF), with and without supplemental irrigation, compared with an untreated control, with and without supplemental irrigation, over a range of leaf area indices (LAI), seasonal evapotranspiration (ETo), and vapor pressure deficits (VPD) to determine the mechanisms of action affecting WUE in apple. Short-term whole canopy gas exchange studies and isotope discrimination analysis were used to test the hypothesis that WUE was modified by the use of a PF. In whole canopy gas exchange studies, carbon assimilation (A) and transpiration tended to increase, and WUE and canopy conductance tended to decrease, with VPD within each LAI class from 2 to 6 . For VPD $>1 \mathrm{kPa}$, the PF irrigated treatment consistently had the greatest WUE and other treatments were intermediate for LAI of 2 to 4 . The PF irrigated and non-irrigated treatments had greater WUE than the control irrigated and non-irrigated treatments for $V P D \leq 2 \mathrm{kPa}$ and there were no treatment effects for VPD $>2$ $\mathrm{kPa}$ in the LAI range of 4 to 6 . The PF non-irrigated was equivalent to the control non-irrigated treatment at VPD of 1 to $3 \mathrm{kPa}$, but was significantly lower at VPD of 3 to $4 \mathrm{kPa}$. PF irrigated and non-irrigated treatments had the greatest carbon isotope discrimination $\left(\Delta^{13} \mathrm{C}\right)$, the control non-irrigated treatment had the lowest $\Delta^{13} \mathrm{C}$, and the controlirrigated treatment was intermediate. Oxygen isotope enrichment $\left(\delta^{18} \mathrm{O}\right)$ was positively correlated with the mean growing season VPD and mean growing season evapotranspiration. $\Delta^{13} \mathrm{C}$ was significantly and positively correlated with $\delta^{18} \mathrm{O}$. Seasonal WUE was negatively correlated with $\Delta^{13} \mathrm{C}$ and there was an interaction with LAI. The seasonal water use of apple is better evaluated with stable isotope discrimination integrating seasonal variation rather that the use of whole canopy gas exchange measurements that measure WUE for brief periods of time. $\Delta^{13} \mathrm{C}$ was an accurate measurement of apple WUE and indicated that the PF irrigated treatment had the greatest $\Delta^{13} \mathrm{C}$ and so the lowest WUE compared with the control non-irrigated treatment at LAI from 4 to 6 . The reduced WUE of the PF irrigated treatment compared with the control non-irrigated treatment is likely due to increased $g_{S}$ from lower canopy temperature and increased canopy photosynthetically active radiation diffusion that drove increased $\mathrm{A}$. $\delta^{18} \mathrm{O}$ was an indicator of seasonal water use over six growing seasons due to its high correlation with ETo. In 'Empire' apple, A can be increased with PF and irrigation treatments, but at the cost of decreased WUE.
\end{abstract}

Water use efficiency (WUE) or transpiration efficiency, the ratio of carbon assimilation to transpiration (E), is a conservative characteristic of species and cultivars (Jones, 1992, 2004). The conservative nature is due to genetic and environmental relationships coupling the plant to its environment. Genetic effects on WUE include the effects of rootstock (Bongi et al., 1994; Cohen and Naor, 2002; Li et al., 2002) and scions (Glenn et al., 2000, 2006). While the genetic mechanism effects on WUE have not been fully described (Morison et al., 2008), hydraulic resistance has been identified as a likely component (Cohen and Naor, 2002; Li et al., 2002) in addition to an efficient root system (Sharp et al., 2004). In reviewing WUE literature of annual crops, Blum (2005) concluded that the

Received for publication 23 Sept. 2009. Accepted for publication 14 Jan. 2010. I wish to thank the Engelhard Corporation and Tessenderlo Kerley, Inc., for their partial financial support of this research.

Mention of a trademark, proprietary product, or vendor does not constitute a guarantee or warranty of the product by the U.S. Department of Agriculture and does not imply its approval to the exclusion of other products or vendors that also may be suitable.

${ }^{1}$ Corresponding author. E-mail: michael.glenn@ars.usda.gov. genotypic variations in WUE were due to variation in water use rather than variation in plant production, resulting in changes to the calculated WUE. For this reason, he argues that selecting for high WUE under water stress in breeding programs will not lead to high biomass/yield under water-limited conditions, but rather to small plants using less water. However, Glenn et al. (2006) identified peach (Prunus persica) cultivars that were higher in WUE and increased yield under rain-fed conditions. Masle et al. (2005) identified a gene, ERECTA, in Arabidopsis thaliana that regulates WUE through biochemical and morphological effects on the plant. The ERECTA gene transformants increased WUE in well-watered and water-stressed conditions in gas exchange studies as well as whole plant water use and biomass accumulation, and the authors indicated that there is a potential to develop drought-resistant lines that can maintain high productivity, contrary to the assertion of Blum (2005).

Environmental effects on WUE include the response to the abiotic environmental effects of vapor pressure deficits (VPD), photosynthetically active radiation $(P A R)$, and water deficits in addition to the physical difference in diffusion in air between 
carbon dioxide and water (Bacon, 2004). WUE generally decreases with increasing VPD (Flore et al., 1985; Masle et al., 2005; Testi et al., 2008), increases with intercepted $P A R$ to a maximum and then decreases (Glenn et al., 2006; LeRoux et al., 2001), and increases with water stress as productivity is reduced (Blum, 2005; Jones, 2004). Cultural manipulation, apart from irrigation, can also affect WUE. Pruning, training, thinning, and other cultural practices that modify leaf area and leaf area index (LAI) will affect WUE. The WUE of shaded leaves is considerably less than illuminated leaves (Xiloyannis et al., 2000), and WUE decreases along light gradients within plant canopies (LeRoux et al., 2001); however, at the ecosystem scale, WUE increases with LAI (Beer et al., 2007). Similarly, increasing $P A R$ within the canopy will increase WUE (Glenn et al., 2006; Green et al., 1995; LeRoux et al., 2001), and overall plant productivity is directly proportional to canopy interception of PAR (Robinson and Lakso, 1991). Wibbe and Blanke (1995) demonstrated that fruit removal before fruit maturity would increase WUE by decreasing canopy $\mathrm{E}$ more than $\mathrm{A}$, while the fruit contributed less than $2 \%$ of the total water use. Partial root zone drying (PRD) as an irrigation technique has also improved WUE in some perennial crops (Davies et al., 2000; Loveys et al., 2004), including apple (Caspari et al., 2004; Leib et al., 2006; Zegbe and Behboudian, 2008) and peach (Goldhammer et al., 2002).

There are techniques to measure WUE on time scales from seconds to a complete growing season. Gas exchange and the calculation of WUE are measured on a real-time basis at the leaf (Parkinson et al., 1980) and whole canopy level (Garcia et al., 1990; Wullschleger et al., 1998). Natural abundance, stable isotopic carbon ratios provide a means to evaluate an integration of WUE for periods of time from days to a complete season (Barbour et al., 2004; Farquhar and Richards, 1984; Sheshshayee et al., 2005). Barbour et al. (2004) have demonstrated a strong negative relationship between oxygen isotope ratios of wheat leaves and stomatal conductance $\left(g_{\mathrm{S}}\right)$ that is independent of A. They also demonstrated that enrichment of ${ }^{18} \mathrm{O}$ can be due to environmental demand, primarily VPD, or $g_{\mathrm{S}}$ (Gc). The correlation of oxygen and carbon isotopic ratios further indicates whether variation in carbon isotopic ratios, and so WUE, is due primarily to Gc, an insensitivity of oxygen isotope discrimination to Gc, or to changes in photosynthetic capacity (Barbour and Farquhar, 2000). Conversely, Sheshshayee et al. (2005) have demonstrated a positive correlation between ${ }^{18} \mathrm{O}$ enrichment of leaf tissues and mean transpiration rate while the degree of ${ }^{18} \mathrm{O}$ can serve as a measure of $\mathrm{Gc}$ at a specific VPD.

This study examined the interaction between a particle film (PF) treatment and WUE response of irrigated and nonirrigated apple trees over a wide range of environmental conditions. Previous work (Glenn et al., 2003) indicated that a PF treatment had reduced WUE in apple in association with increased canopy photosynthesis, water use, and subsequent increased fruit size. The objectives were to measure isotopic discrimination $\left(\Delta^{13} \mathrm{C}\right.$ and $\left.\delta^{18} \mathrm{O}\right)$, specific gas exchange, and WUE response of 'Empire' apple treated with a $\mathrm{PF}$, with and without supplemental irrigation, compared with an untreated control, with and without supplemental irrigation, over a range of LAI, seasonal evapotranspiration, and VPD to determine the mechanisms of action affecting WUE in apple. Short-term whole canopy gas exchange studies and isotope discrimination analysis were used to test the hypothesis that WUE was modified by the use of a reflective PF.

\section{Materials and Methods}

Materials. The apple orchard was a moderate density planting (500 trees/ha) of 'Empire'/'M.7A' planted in 1992 at the U.S. Department of Agriculture, Agricultural Research Service, Appalachian Fruit Research Station in Kearneysville, WV. Tree water requirements were based on $70 \%$ of pan evaporation (Glenn, 1995, 1999). Irrigation treatments consisted of two drip emitters per tree receiving the daily water needs. Treatments were randomly assigned in 2003 in a splitplot block design with irrigation as the main plot and PF treatment as the subplot with six single-tree replicates. In 2005, treatments were randomly assigned and the same treatment assignments were maintained in 2006 and 2007 in a split-plot block design with irrigation as the main plot and PF treatment as the subplot with six single-tree replicates. In all years, the trees were hand-thinned post-bloom. Trees received a PF treatment or were not treated. All treatments were over-sprayed with conventional pesticides to protect from disease or insect damage. Conventional orchard practices were used in tree training and weed control. At harvest, all fruit were weighed and counted for each tree in a plot. Fruit from each tree were processed with an electronic grader that counted and weighed each fruit.

Apple trees received applications of a highly reflective, white, hydrophilic particle based on kaolin mineral (Surround WP ${ }^{\mathrm{TM}}$; NovaSource, a division of Tessenderlo Kerley, Phoenix) in addition to a conventional pesticide spray program. The mineral was processed to a bright white color of $>90 \%$ reflectance, with mean particle size $<2 \mu \mathrm{m}$ in diameter. From 2003 to 2007 , a $2.85 \%$ mixture of $95 \%$ a.i. Surround WPTM or its earlier prototype, M97-009, was applied. The Surround WP'M and M97-009 treatments were applied at the rate of $935 \mathrm{~L} \cdot \mathrm{ha}^{-1}$ $(\approx 50 \%$ of tree row volume) using an air blast sprayer. There was an untreated control treatment. PF treatments were applied every 2 weeks following petal fall until 2 to 3 weeks before harvest.

Fruit maturity parameters. In all studies, fruit were harvested at optimum maturity for storage based on firmness, starch, and soluble solids concentration. Harvest and maturity data are presented in Glenn (2009). A subsample of 10 fruit were weighted and then air-dried at $70{ }^{\circ} \mathrm{C}$ for $\approx 1$ week to determine dry weight and water content. The fruit water content was used to calculate the total dry weight of the fruit harvested from each tree. Samples were collected in 2001 and 2002 from similar studies (Glenn et al., 2003).

Whole CANOPY Net CARbon ASSimilation CHAMber. The whole canopy carbon assimilation chamber used in 2003 and 2005 was constructed of 0.08-mm-thick polyester film (Mylar Type D; DuPont, Wilmington, DE). Six vertical panels were attached with Velcro ${ }^{\circledR}$ tape to a circular top. The bottom was constructed from an oversized square of 0.15-mm-thick polyethylene plastic that was rolled up with the Mylar sides and then clamped every $15 \mathrm{~cm}$. The bottom panel had a radial cut to enclose the tree and was sealed with Velcro. The bottom panel was tied to the tree for a tight fit at a point immediately below the first scaffold branch, generally 30 to $50 \mathrm{~cm}$ above the soil. The top and bottom panels were $2.1 \mathrm{~m}$ in diameter and the vertical panels were $2.1 \mathrm{~m}$ high, resulting in a volume of $7.5 \mathrm{~m}^{3}$. 
A hoop-structure of 13-mm-diameter electrical conduit was erected over each tree. Four components of the structure were joined together at the apex of the tree and the four conduit legs were attached to steel rods, hammered into the soil at the perimeter of the tree. The Mylar chamber was placed over the metal conduit structure. The vertical panels and the bottom panel were gathered and folded around the metal structure. The outlet port was a $30-\mathrm{cm}$ hole in the top panel.

The whole canopy carbon assimilation chamber used in 2006 and 2007 was constructed of 0.762-mm-thick polycarbonate (Makrolon GP; Sheffield Plastics-Bayer Material Sciences, Pittsburgh) in a rigid cube $2.4 \times 2.4 \times 2.4 \mathrm{~m}$. A framed polycarbonate pitched roof covered the cube and the floor was a polyethylene tarp material split to the center to slide onto the tree and was sealed with a Velcro strip.

Air was forced into each chamber with a 1-hp fan attached to a metal conduit with a cross-sectional area of $777 \mathrm{~cm}^{2}$. Five holes were drilled in the conduit to measure air velocity with a velometer (model 8346; TSI, Shoreview, MN), and $102.5-\mathrm{cm}$ positions at each sample port were measured at the beginning and end of the sampling period. Velocity data were averaged to calculate mass air flux. Air was forced into the chamber by inserting the conduit into the seam of two vertical panels and the bottom panel in 2003 and 2005. In 2006 and 2007, air was forced into the chamber from below the cuvette through a diffusion grate located $50 \mathrm{~cm}$ from the tree trunk. Leaf movement was visually assessed to insure that no large eddies developed in the chamber. About 6 chamber volumes were exchanged per minute, and this air flow maintained the internal air temperature 1 to $2{ }^{\circ} \mathrm{C}$ above ambient. Air temperature was measured with a shielded thermocouple hanging $\approx 30 \mathrm{~cm}$ into the chamber through the outlet port. Whole canopy net $\mathrm{CO}_{2}$ and $\mathrm{H}_{2} \mathrm{O}$ exchange were measured with an infrared gas analyzer (IRGA; CIRAS-1; PP Systems, Haverhill, MA) from the difference in $\mathrm{CO}_{2}$ and $\mathrm{H}_{2} \mathrm{O}$ concentration between the inlet (reference) and the outlet (analysis) ports of each chamber. Equal lengths of tubing were inserted into the conduit and the outlet port, and the sampled air was drawn to the IRGA with a pump. Response time was 5 to $10 \mathrm{~s}$. The sampled air was blown into a cylinder that was sampled by the IRGA with its own sampling pumps. Multiple chambers were sampled sequentially at 1-min intervals using a programmable controller (SDM-CD16AC; Campbell Scientific, Logan, UT) that controlled solenoid valves on the reference and analysis tubes of each chamber. The controller was programmed and data were collected with a datalogger (CR-7; Campbell Scientific).

Diurnal data were collected on the following dates: 15-21 Aug. 2003, 5-11 Aug. 2005, 5-13 Aug. 2006, and 13-21 Sept. 2007. During each annual sampling study, two trees of each treatment were simultaneously measured for 2 to $3 \mathrm{~d}$. The chambers were moved to two other trees within the treatment providing four single-tree replications of whole tree gas exchange. PAR, relative humidity, wind speed, pan evaporation, and air temperature were measured at a weather station $\approx 500 \mathrm{~m}$ from the measurement site. Data were collected for 24 h each day but only data from 0900 to 1900 HR were analyzed.

Whole canopy conductance $\left(\mathrm{mmol} \cdot \mathrm{m}^{-2} \cdot \mathrm{s}^{-1} \mathrm{H}_{2} \mathrm{O}\right)$ was calculated according to Campbell and Norman (1998) using transpiration values from 900 to $1900 \mathrm{HR}$ pooled overall treatments and sampling dates within a year.

Following harvest, the trees sampled for whole canopy carbon assimilation were covered with a netting to capture all the leaves when they abscised. The leaves were collected and air-dried at $70{ }^{\circ} \mathrm{C}$ for $\approx 1$ week. At sampling, a subsample of $\approx 3 \mathrm{~kg}$ fresh weight was separated, leaf area was measured, and the ratio of air-dried weight:leaf area was calculated. This ratio was used to convert the total air-dried weight of each tree to total leaf area. LAI was the quotient of the total leaf area divided by the area of the canopy shadow measured within $1 \mathrm{~h}$ of solar noon.

Tissue Analysis. Particle density on the leaves was measured by wash-off of four leaves per tree at each sampling and ranged from 2 to $4 \mathrm{~g} \cdot \mathrm{m}^{-2}$. Preweighed tissue paper was wetted and used to rub the residue from the upper surface of the leaf. The tissue paper was air-dried and reweighed. Leaf area was measured. Four control leaves were also measured. Particle density was calculated as the increase in tissue weight (grams) divided by the leaf area $\left(\mathrm{m}^{2}\right)$. The mean control leaf particle density was subtracted from each PF treatment.

Four 30-cm terminal shoot samples per tree were collected in the dormant season and the buds were removed. The tissue was dried at $70{ }^{\circ} \mathrm{C}$ for $72 \mathrm{~h}$, ground, and analyzed for ${ }^{13} \mathrm{C}$ and ${ }^{18} \mathrm{O}$ content (Davis Stable Isotope Facility, University of California, Davis). Isotopic carbon discrimination $\left(\Delta^{13} \mathrm{C}\right)$ was calculated according to Farquhar et al. (1989). The isotopic composition of carbon dioxide in air $\left(\delta{ }^{13} \mathrm{C}_{\text {air }}\right)$ was assumed to be $-7.8 \mathrm{~g} \cdot \mathrm{L}^{-1}$ (Francey et al., 1995). Isotopic oxygen enrichment $\left(\delta^{18} \mathrm{O}\right)$ was calibrated against a cellulose standard that was calibrated against standard mean ocean water (SMOW). Samples were collected in 2001 and 2002 from similar studies (Glenn et al., 2003).

Statistical analysis. PF and irrigation effects on whole canopy A, E, WUE, and Gc from 0900 to $1900 \mathrm{HR}$ for LAI values of 2 to 4 and 4 to 6 , and VPD values of $<1,1$ to 2,2 to 3 , and 3 to $4 \mathrm{kPa}$ were analyzed over all years using analysis of covariance in which $P A R$ values were the independent covariate. There was no interaction with year, and the data were

Table 1. Temperature, $P A R$, vapor pressure deficit, and leaf area index characterizing the gas exchange sampling periods in 2003 and 2005-07 for 'Empire' apple in Kearneysville, WV.

\begin{tabular}{lccc}
\hline & \multicolumn{3}{c}{ Temperature $\left({ }^{\circ} \mathrm{C}\right)$} \\
\cline { 2 - 4 } Yr & Mean & Maximum & Minimum \\
\hline 2003 & 28.0 & 32.3 & 23.0 \\
2005 & 28.4 & 33.9 & 21.9 \\
2006 & 26.9 & 29.1 & 18.9 \\
2007 & 20.1 & 10.0 \\
& Photosynthetically active radiation $\left(\mu \mathrm{mol} \cdot \mathrm{m}^{-2} \cdot \mathrm{s}^{-1}\right)$ \\
2003 & 895 & 1801 & 26 \\
2005 & 1065 & 1921 & 59 \\
2006 & 1189 & 1554 & 77 \\
2007 & 886 & & 35 \\
& & & \\
2003 & 1.56 & 3.40 & 0.48 \\
2005 & 1.67 & 3.30 & 0.29 \\
2006 & 1.98 & 2.01 & 0.37 \\
2007 & 1.11 & Vapor pressure deficit $(\mathrm{kPa})$ & 0.10 \\
& & 3.3 & \\
2003 & 3.0 & 4.2 & 2.6 \\
2005 & 3.2 & 6.0 & 2.6 \\
2006 & 5.6 & 5.0 & 3.5 \\
2007 & 4.4 & &
\end{tabular}


pooled over years. There was a $\mathrm{PF} \times$ irrigation interaction. Data were analyzed using SAS (version 8; SAS Institute, Cary, NC). Adjusted treatment means were compared using PDIFF, which compares least squares means from the analysis of covariance. Treatment means were compared using Fisher's protected least significant difference (LSD) at $P \leq 0.05$.

$\mathrm{PF}$ and irrigation effects on isotopic discrimination of ${ }^{13} \mathrm{C}$ and ${ }^{18} \mathrm{O}$ content were analyzed over years using analysis of covariance with independent covariates of LAI, VPD, ETo, and WUE using SAS (version 8). Seasonal water use efficiency (SWUE) was calculated as the ratio of fruit + leaf biomass (kilograms):mean growing season ETo (centimeters). Adjusted treatment means were compared using PDIFF, which compares least squares means from the analysis of covariance. Treatment means were compared using LSD at $P \leq 0.05$. When there were no significant treatment effects, data were pooled by year for regression analysis.

\section{Results}

GAS EXCHANGE STUDiEs. In the 4 years of the study, a range of LAI developed and was exposed to a range of growing season temperatures, PAR, and VPD levels (Table 1). These data provided environmental and biological variation to evaluate tree response to the PF and irrigation treatments. In general, A and E tended to increase, and WUE and Gc tended to decrease with VPD within each LAI class from 2 to 6 (Table 2). The PF irrigated treatment consistently had the greatest $\mathrm{A}$, and the control non-irrigated treatment generally had the lowest A for the LAI range of 2 to 4 . Other treatments were intermediate and

Table 2. Particle film treatment effects on the mean daily photosynthesis (A), transpiration (E), water use efficiency (WUE), and canopy conductance (Gc) response of 'Empire' apple at three leaf area index (LAI) levels for four vapor pressure deficit (VPD) levels. Data are pooled over four sampling years.

\begin{tabular}{|c|c|c|c|c|c|c|c|}
\hline \multirow[b]{2}{*}{ LAI } & \multirow[b]{2}{*}{ VPD $(\mathrm{kPa})$} & \multirow[b]{2}{*}{ Treatment } & \multirow[b]{2}{*}{ Irrigation } & \multicolumn{4}{|c|}{ Mean daily gas exchange } \\
\hline & & & & $\begin{array}{c}\mathrm{A}\left[\mathrm{CO}_{2}\right. \\
\left.\left(\mu \mathrm{mol} \cdot \mathrm{m}^{-2} \cdot \mathrm{s}^{-1}\right)\right] \\
\end{array}$ & $\begin{array}{c}\mathrm{E}\left[\mathrm{H}_{2} \mathrm{O}\right. \\
\left.\left(\mathrm{mmol} \cdot \mathrm{m}^{-2} \cdot \mathrm{s}^{-1}\right)\right] \\
\end{array}$ & $\begin{array}{c}\text { WUE } \\
\left(\mu \mathrm{mol} \cdot \mathrm{mmol}^{-1} \mathrm{H}_{2} \mathrm{O}\right)\end{array}$ & $\begin{array}{c}\mathrm{Gc}\left[\mathrm{H}_{2} \mathrm{O}\right. \\
\left.\left(\mathrm{mmol} \cdot \mathrm{kPa}^{-1}\right)\right]\end{array}$ \\
\hline $2-4$ & $<1$ & Control & Irrigated & $4.07^{\mathrm{xy}} \mathrm{b}$ & $0.92^{\mathrm{y}} \mathrm{b}$ & $4.49^{\mathrm{y}} \mathrm{a}$ & $128.51^{\mathrm{y}} \mathrm{b}$ \\
\hline $2-4$ & $<1$ & Control & Non-irrigated & $4.90 \mathrm{~b}$ & $1.26 \mathrm{a}$ & $4.04 \mathrm{a}$ & $178.95 \mathrm{a}$ \\
\hline $2-4$ & $<1$ & $\mathrm{PF}^{\mathrm{z}}$ & Irrigated & $5.78 \mathrm{a}$ & $1.26 \mathrm{a}$ & $4.69 \mathrm{a}$ & $168.25 \mathrm{a}$ \\
\hline $2-4$ & $<1$ & $\mathrm{PF}$ & Non-irrigated & $4.60 \mathrm{~b}$ & $1.38 \mathrm{a}$ & $3.79 \mathrm{a}$ & $186.47 \mathrm{a}$ \\
\hline $2-4$ & $1-2$ & Control & Irrigated & $4.58 \mathrm{c}$ & $1.80 \mathrm{~b}$ & $2.72 \mathrm{~b}$ & $117.09 \mathrm{~b}$ \\
\hline $2-4$ & $1-2$ & Control & Non-irrigated & $5.87 \mathrm{~b}$ & $2.66 \mathrm{a}$ & $2.30 \mathrm{c}$ & $172.96 \mathrm{a}$ \\
\hline $2-4$ & $1-2$ & $\mathrm{PF}$ & Irrigated & $7.16 \mathrm{a}$ & $2.52 \mathrm{a}$ & $3.00 \mathrm{a}$ & $165.72 \mathrm{a}$ \\
\hline $2-4$ & $1-2$ & $\mathrm{PF}$ & Non-irrigated & $5.77 \mathrm{~b}$ & $2.55 \mathrm{a}$ & $2.39 \mathrm{c}$ & $173.07 \mathrm{a}$ \\
\hline $2-4$ & $2-3$ & Control & Irrigated & $4.97 \mathrm{c}$ & $2.48 \mathrm{~b}$ & $2.05 \mathrm{ab}$ & $109.06 \mathrm{~b}$ \\
\hline $2-4$ & $2-3$ & Control & Non-irrigated & $5.71 \mathrm{c}$ & $3.15 \mathrm{a}$ & $1.85 \mathrm{~b}$ & $137.42 \mathrm{a}$ \\
\hline $2-4$ & $2-3$ & $\mathrm{PF}$ & Irrigated & $7.57 \mathrm{a}$ & $3.40 \mathrm{a}$ & $2.28 \mathrm{a}$ & $148.32 \mathrm{a}$ \\
\hline $2-4$ & $2-3$ & $\mathrm{PF}$ & Non-irrigated & $6.59 \mathrm{~b}$ & $3.28 \mathrm{a}$ & $2.06 \mathrm{ab}$ & $144.36 \mathrm{a}$ \\
\hline $2-4$ & $3-4$ & Control & Irrigated & $5.26 \mathrm{~b}$ & $2.90 \mathrm{~b}$ & $1.82 \mathrm{a}$ & $88.14 \mathrm{a}$ \\
\hline $2-4$ & $3-4$ & Control & Non-irrigated & $5.20 \mathrm{~b}$ & $3.27 \mathrm{ab}$ & $1.60 \mathrm{~b}$ & $99.52 \mathrm{a}$ \\
\hline $2-4$ & $3-4$ & $\mathrm{PF}$ & Irrigated & $8.50 \mathrm{a}$ & $4.81 \mathrm{a}$ & $1.77 \mathrm{a}$ & $146.42 \mathrm{a}$ \\
\hline $2-4$ & $3-4$ & $\mathrm{PF}$ & Non-irrigated & $8.47 \mathrm{a}$ & $4.76 \mathrm{a}$ & $1.79 \mathrm{a}$ & $144.78 \mathrm{a}$ \\
\hline $4-6$ & $<1$ & Control & Irrigated & $3.13 \mathrm{~b}$ & 1.81 & $1.89 \mathrm{~b}$ & $317.81 \mathrm{a}$ \\
\hline $4-6$ & $<1$ & Control & Non-irrigated & $2.58 \mathrm{c}$ & 1.46 & $1.98 \mathrm{~b}$ & $272.93 \mathrm{ab}$ \\
\hline $4-6$ & $<1$ & $\mathrm{PF}$ & Irrigated & $4.08 \mathrm{a}$ & 1.46 & $3.41 \mathrm{a}$ & $203.27 \mathrm{~b}$ \\
\hline $4-6$ & $<1$ & $\mathrm{PF}$ & Non-irrigated & $3.35 \mathrm{~b}$ & $1.42 \mathrm{NS}$ & $3.01 \mathrm{a}$ & $212.86 \mathrm{~b}$ \\
\hline $4-6$ & $1-2$ & Control & Irrigated & $3.48 \mathrm{~b}$ & 3.00 & $1.17 \mathrm{c}$ & 216.13 \\
\hline $4-6$ & $1-2$ & Control & Non-irrigated & $3.28 \mathrm{~b}$ & 2.83 & $1.18 \mathrm{c}$ & 202.93 \\
\hline $4-6$ & $1-2$ & $\mathrm{PF}$ & Irrigated & $4.27 \mathrm{a}$ & 2.73 & $1.76 \mathrm{a}$ & 194.64 \\
\hline $4-6$ & $1-2$ & $\mathrm{PF}$ & Non-irrigated & $4.30 \mathrm{a}$ & $3.05 \mathrm{NS}$ & $1.51 \mathrm{~b}$ & $210.00 \mathrm{NS}$ \\
\hline $4-6$ & $2-3$ & Control & Irrigated & 2.70 & 2.99 & 0.88 & 122.22 \\
\hline $4-6$ & $2-3$ & Control & Non-irrigated & 3.03 & 3.24 & 0.91 & 135.44 \\
\hline $4-6$ & $2-3$ & $\mathrm{PF}$ & Irrigated & 3.46 & 3.50 & 1.06 & 142.60 \\
\hline $4-6$ & $2-3$ & $\mathrm{PF}$ & Non-irrigated & $3.65 \mathrm{NS}$ & $4.04 \mathrm{NS}$ & $0.90 \mathrm{NS}$ & $167.49 \mathrm{NS}$ \\
\hline $4-6$ & $3-4$ & Control & Irrigated & $2.46 \mathrm{~b}$ & $3.03 \mathrm{~b}$ & 0.82 & 96.03 b \\
\hline $4-6$ & $3-4$ & Control & Non-irrigated & $2.34 \mathrm{~b}$ & $3.07 \mathrm{~b}$ & 0.92 & $97.66 \mathrm{~b}$ \\
\hline $4-6$ & $3-4$ & PF & Irrigated & $4.14 \mathrm{a}$ & $3.94 \mathrm{~b}$ & 1.07 & $123.89 \mathrm{~b}$ \\
\hline $4-6$ & $3-4$ & $\mathrm{PF}$ & Non-irrigated & $4.36 \mathrm{a}$ & $5.19 \mathrm{a}$ & 0.84 & $164.50 \mathrm{a}$ \\
\hline
\end{tabular}

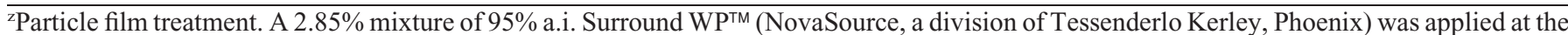
rate of $935 \mathrm{~L} \cdot \mathrm{ha}^{-1}(\approx 50 \%$ of tree row volume) using an air blast sprayer. Treatments were applied every 2 weeks following petal fall. Irrigated indicates full season irrigation. Non-irrigated indicates no supplemental irrigation.

${ }^{y}$ Adjusted means are estimated from analysis of covariance using PAR as the independent covariate and mean separation within LAI and VPD uses SAS (version 8.0; SAS Institute, Cary, NC) Proc PDIFF at $P \leq 0.05$.

${ }^{x}$ Different letters within a column for each level of VPD indicate a significant difference $(P \leq 0.05)$ using Fisher's protected least significant difference. 
the PF irrigated and non-irrigated treatments generally had greater A than the control irrigated and non-irrigated treatments. In the LAI range of 4 to 6 , the PF irrigated treatment had the greatest $\mathrm{A}$ for $\mathrm{VPD} \leq 2 \mathrm{kPa}$, and there were no treatment effects for $\mathrm{VPD}>2 \mathrm{kPa}$. The control irrigated treatment had the lowest $\mathrm{E}$ compared with the other treatments in the LAI range of 2 to 4 . There were no treatment effects on $\mathrm{E}$ in the LAI range of 4 to 6 . There were no treatment effects on WUE for $\mathrm{VPD}<1$ $\mathrm{kPa}$ in the LAI range of 2 to 4 , which generally occur in early morning. For VPD $>1 \mathrm{kPa}$, the $\mathrm{PF}$ irrigated treatment consistently had the greatest WUE, and other treatments were intermediate for LAI of 2 to 4 . The PF irrigated and nonirrigated treatments had greater WUE than the control irrigated and non-irrigated treatments for $\mathrm{VPD} \leq 2 \mathrm{kPa}$, and there were no treatment effects for VPD $>2 \mathrm{kPa}$ in the LAI range of 4 to 6 . The PF non-irrigated was equivalent to the control nonirrigated treatment at VPD of 1 to $3 \mathrm{kPa}$, but was significantly lower at VPD of 3 to $4 \mathrm{kPa}$. The control irrigated treatment had the lowest Gc for VPD $\leq 3 \mathrm{kPa}$, and there were no treatment effects for VPD of 3 to $4 \mathrm{kPa}$ in the LAI range of 2 to 4 . The control irrigated treatment had the greatest canopy conductance for $\mathrm{VPD}<1 \mathrm{kPa}$; the PF treatment had the greatest Gc for VPD from 3 to $4 \mathrm{kPa}$; while there were no treatment effects for VPD between 1 and $3 \mathrm{kPa}$ in the LAI range of 4 to 6 (Table 2).

StABLE ISOTOPE Discrimination STUdies. $\Delta^{13} \mathrm{C}$ and $\delta^{18} \mathrm{O}$ were positively correlated to LAI ( $\mathrm{r}=0.45$ and 0.33 , respectively); however, there were no treatment effects on $\delta^{18} \mathrm{O}$ response. Analysis of covariance using LAI as the covariate (Fig. 1) indicated that PF irrigated and non-irrigated treatments had the greatest $\Delta^{13} \mathrm{C}$, the control non-irrigated treatment had the lowest $\Delta^{13} \mathrm{C}$, and the control irrigated treatment was intermediate $(P=0.05)$.

$\delta^{18} \mathrm{O}$ was positively correlated with the mean growing season VPD (Fig. 2A) and mean growing season evapotranspiration (Fig. 2B). Analysis of covariance using VPD or ETo as the covariate indicated that there were no significant treatment

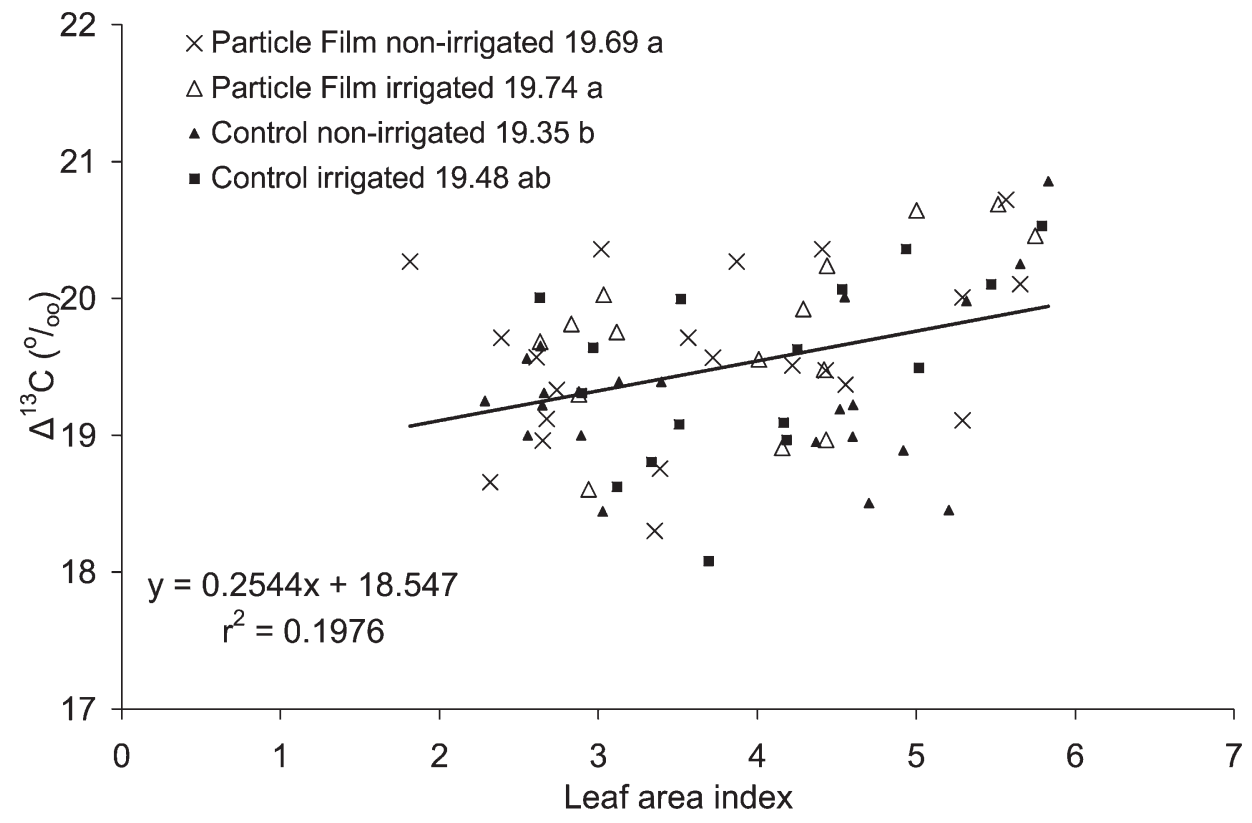

Fig. 1. Relationship between leaf area index and isotopic discrimination of $\Delta^{13} \mathrm{C}$ for four particle film treatments in 'Empire' apple at Kearneysville, WV, for 2003 and 2005-07. Values in the figure legend are the adjusted mean values from analysis of covariance $(P=0.05)$. Different letters for each mean level of $\Delta^{13} \mathrm{C}$ discrimination indicate a significant difference $(P \leq 0.05)$ using Fisher's protected least significant difference. effects on $\delta^{18} \mathrm{O}$ for the 6 years of the study (data not presented). $\Delta^{13} \mathrm{C}$ was not correlated with VPD or ETo, and there were no significant treatment effects for the $\Delta^{13} \mathrm{C}$ response over 6 years (data not presented). $\Delta^{13} \mathrm{C}$ was significantly and positively correlated with $\delta^{18} \mathrm{O}\left(\delta^{18} \mathrm{O}=0.2565 \Delta^{13} \mathrm{C}+15.847 ; \mathrm{r}=0.27\right)$. Analysis of covariance using $\delta^{18} \mathrm{O}$ as the covariate indicated that the PF irrigated treatment had the greatest $\Delta{ }^{13} \mathrm{C}$, which was not significantly different from the PF non-irrigated or control irrigated treatments, but was significantly greater than the control non-irrigated treatment $(19.63,19.79,19.36$, and 19.49, respectively, for the adjusted mean $\Delta^{13} \mathrm{C}, P=0.05$ ).

SWUE was negatively correlated with $\Delta^{13} \mathrm{C}$, and there was an interaction with LAI. Analysis of covariance by LAI range indicated there were no significant treatment effects on $\Delta^{13} \mathrm{C}$ response for the LAI range of 2 to 4 (Fig. 3A). In the LAI range of 4 to 6 , analysis of covariance indicated that the $\mathrm{PF}$ irrigated treatment had the greatest $\Delta^{13} \mathrm{C}$, which was not significantly different from the PF non-irrigated or control irrigated treatments, but was significantly greater than the control nonirrigated treatment (Fig. 3B).

\section{Discussion}

The daily mean $\mathrm{A}$ and $\mathrm{E}$ of the PF treatment, whether irrigated or non-irrigated, was always equal to or greater than the control treatments for the range of VPD and LAI. This is similar to the midday A of these treatments and accounts in large part for the increased fruit mass reported in the studies (Glenn, 2009). The WUE of the PF treatments was generally equivalent to or greater than the control treatments. However, at VPD of 1 to $2 \mathrm{kPa}$, the $\mathrm{PF}$ non-irrigated treatment had the lowest WUE for LAI of 2 to 4, indicating no consistent trend. The PF irrigated and non-irrigated treatments had Gc equivalent to or greater than the control treatments in all conditions, except for VPD $<1 \mathrm{kPa}$ at LAI of 4 to 6 when the control irrigated treatment had the greatest $\mathrm{Gc}$, again indicating the lack of a consistent trend in gas exchange.

Whole canopy gas exchange systems are valuable in identifying the environmental factors driving and limiting gas exchange and WUE for the time frame of the study, but must be used on a frequent basis to evaluate seasonal treatment effects on WUE. The integral of WUE over the growing season is dominated by the plant response when the stomata are most open, whereas in whole canopy gas exchange studies evaluating daily responses, the plant WUE during the day is simply averaged. Wibbe and Blanke (1995) measured WUE of fruiting and defruited apple trees in whole canopy gas exchange systems during the last half of the growing season. Before harvest in October, WUE was reduced by the presence of fruit in August and September, but increased in October while WUE generally declined from August through October, indicating 


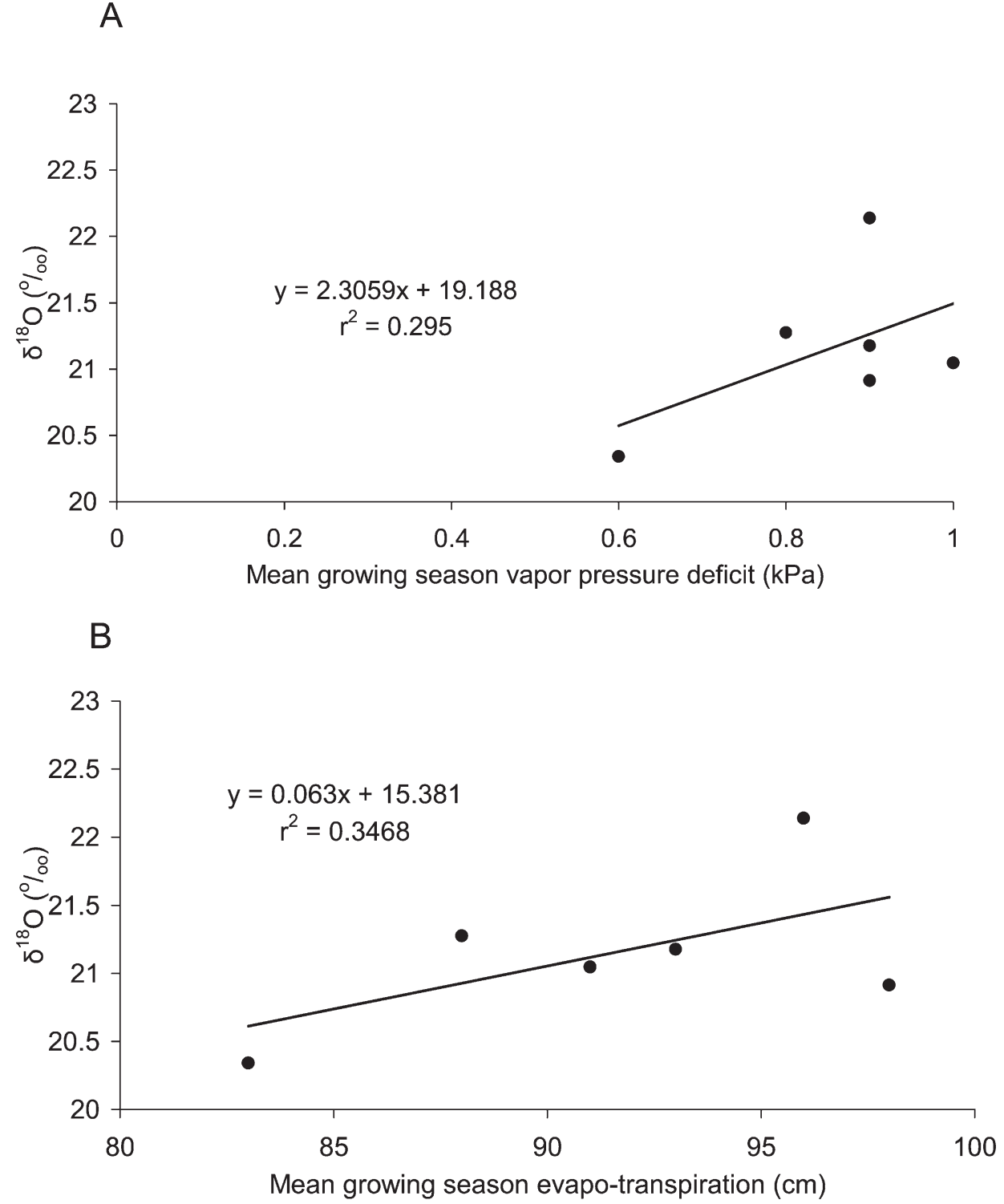

Fig. 2. Relationship between isotopic discrimination of $\delta^{18} \mathrm{O}$ and the mean growing season vapor pressure deficit (A) and the mean growing season evapotranspiration (B) of 'Empire' apple at Kearneysville, WV, for 2003 and 2005-07.

that infrequent measurement of WUE is not an accurate estimate of the dynamics of seasonal WUE. The whole canopy gas exchange studies were conducted in July and August because shoot expansion had essentially ceased for the growing season and leaf collection in the fall would be an accurate measurement of leaf area to calculate A, E, and Gc. Measurements collected before shoot expansion ceased would rely on estimates of leaf area, although WUE alone could be accurately measured without leaf area data. The only consistent effect of the PF treatments was that the mean daily $\mathrm{A}$ was equal to or greater than the control treatments over a range of LAI and VPD, but this had no consistent effect on WUE as measured in these short-term studies.

Stable isotope analysis of ${ }^{13} \mathrm{C}$ and ${ }^{18} \mathrm{O}$ has proven to be a reliable indicator of gas exchange and WUE properties in plants (Barbour et al., 2004; Farquhar and Richards, 1984; Sheshshayee et al., 2005). The daily WUE value pooled over treatments and years for the 2 to 4 LAI range was significantly greater than for the 4 to 6 LAI range ( Table $1 ; 2.70$ vs. 1.64 umol $\cdot \mathrm{mmol}^{-1}$, respectively, $P=$ 0.05). Analysis of covariance for $\Delta^{13} \mathrm{C}$ response also demonstrated that increasing LAI increased $\Delta^{13} \mathrm{C}$ and so decreased WUE (Fig. 1). These results are supported by the observation that the WUE of shaded leaves is considerably less than illuminated leaves (Xiloyannis et al., 2000), that WUE decreases along light gradients within plant canopies (LeRoux et al., 2001), and that increasing $P A R$ within the canopy will increase WUE (Glenn et al., 2006; Green et al., 1995; LeRoux et al., 2001). In addition, the PF irrigated treatment had the greatest $\Delta^{13} \mathrm{C}$, indicating reduced WUE compared with the control non-irrigated treatment over the range of LAI. The increase in $\Delta^{13} \mathrm{C}$ with the PF irrigated treatment suggests increased $g_{\mathrm{S}}$ for significant periods of time throughout the growing season, resulting in increased $\Delta^{13} \mathrm{C}$ and reduced WUE, whereas the mean daily canopy conductance measured in whole canopy studies provided little indication of increased conductance (Table 1). Glenn (2009) did demonstrate that the PF irrigated treatment was able to maintain higher A during conditions of high light intensity and high VPD compared with the other treatments, supporting the hypothesis that $g_{\mathrm{S}}$ was greater.

The positive correlation of $\delta^{18} \mathrm{O}$ with VPD (Fig. 2A) is similar to other studies with annual crops (Farquhar et al., 2007; Sheshshayee et al., 2005), and the linear correlation of $\delta^{18} \mathrm{O}$ with seasonal ETo (Fig. 2B) combines the linkage of $\delta^{18} \mathrm{O}$ to the VPD because VPD is a key component of ETo, but also the use of $\delta^{18} \mathrm{O}$ as a measure of transpiration (Sheshshayee et al., 2005) because seasonal E would be expected to linearly increase with ETo. The linear relationship of $\delta^{18} \mathrm{O}$ with ETo supports the calculation of SWUE as the ratio of fruit and leaf dry weight biomass to ETo because ETo would be expected to reflect the seasonal water use of the tree. As in other studies (Barbour et al., 2004; Farquhar and Richards, 1984; Impa et al., 2005), $\Delta^{13} \mathrm{C}$ is negatively correlated with a measurement of WUE; in this study, SWUE is the measure of WUE (Fig. 3, A and B); however, there is an interaction with LAI in which no significant treatment differences are indicated for LAI of 2 to 4 (Fig. 3A), but for LAI of 4 to 6 , PF irrigated treatment had the greatest $\Delta^{13} \mathrm{C}$ and the control non-irrigated treatment had the lowest $\Delta^{13} \mathrm{C}$ (Fig. 3B). This interaction is likely due to the reduced canopy temperature and the increased diffusion of light into the canopy from the reflective PF (Glenn, 2009; Glenn and Puterka, 2007; Rosati et al., 

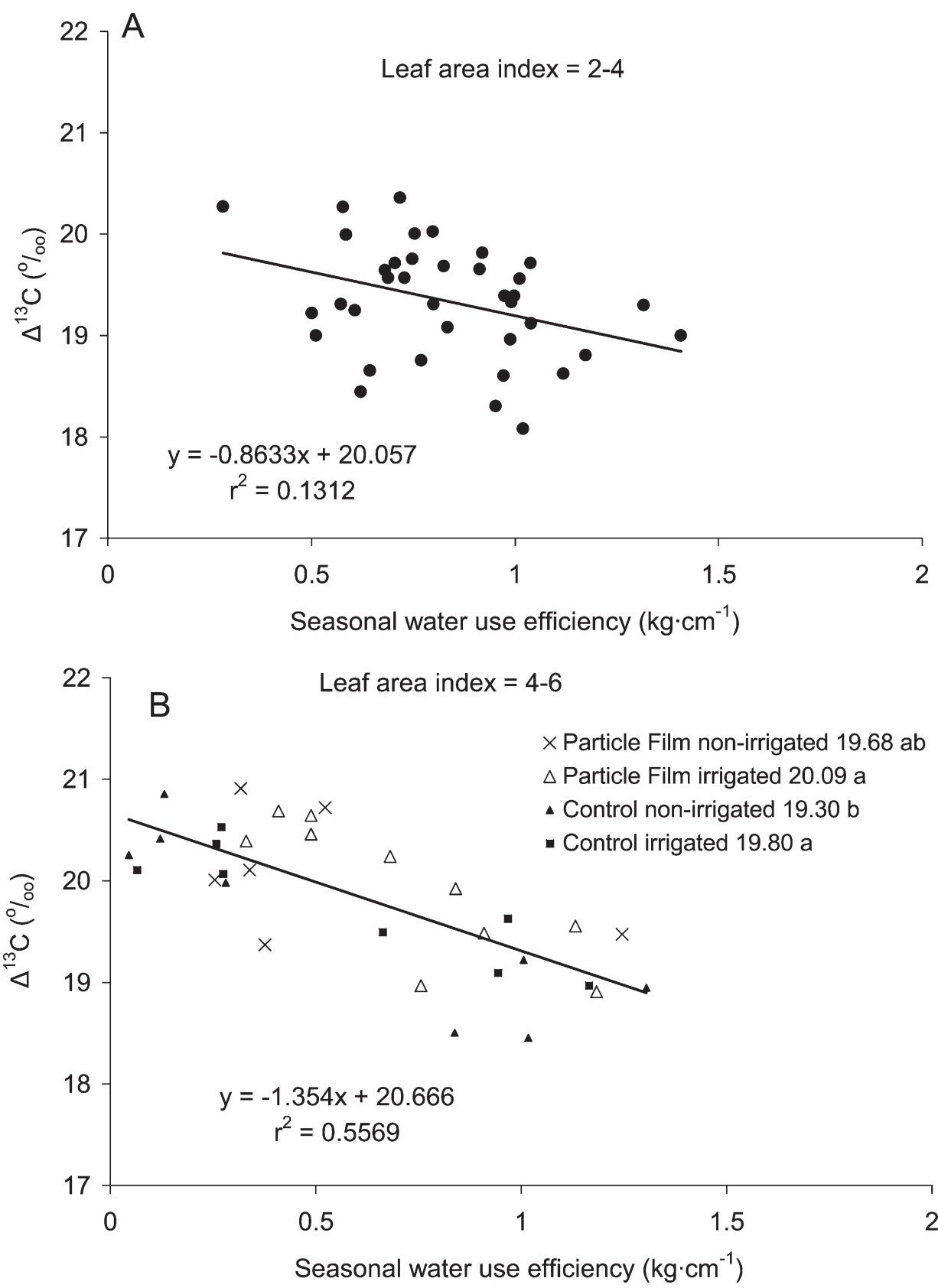

Fig. 3. Relationship between seasonal water use efficiency and isotopic discrimination of $\Delta^{13} \mathrm{C}$ pooled over four particle film treatments (A) and for four particle film treatments in 'Empire' apple at Kearneysville, WV, for 2003 and 2005-07 (B). Values in the figure legend are the adjusted mean values from analysis of covariance $(P=$ 0.05). Different letters for each mean level of $\Delta^{13} \mathrm{C}$ discrimination indicate a significant difference $(P \leq 0.05)$ using Fisher's protected least significant difference.

$2007)$ that would increase $g_{\mathrm{S}}$ compared with the non-irrigated control treatment at LAI of 4 to 6 . Trees with LAI of 4 to 6 would have more internal shading and would benefit more from $P A R$ diffusion by the reflective PF than more open tree architectures with an LAI of 2 to 4.

The low correlation between $\Delta^{13} \mathrm{C}$ and $\delta^{18} \mathrm{O}$ and the shallow slope $\left(\delta^{18} \mathrm{O}=0.2565 \Delta^{13} \mathrm{C}+15.847 ; \mathrm{r}=0.27\right)$ indicate that the sensitivity of $\delta^{18} \mathrm{O}$ to $g_{\mathrm{S}}$ is low or that a portion of the variability in $\Delta^{13} \mathrm{C}$ is caused by changes in the photosynthetic capacity (Barbour and Farquhar, 2000). Because the $\Delta^{13} \mathrm{C}$ and $\delta^{18} \mathrm{O}$ data are derived from stem cellulose tissue and not leaf tissue, there is dampening of the leaf signal that is stored in stem cellulose (Saurer et al., 1997), thus it is not clear how to interpret the low correlation of these stable isotope discrimination values that are generally well correlated in other studies (Barbour and Farquhar, 2000; Saurer et al., 1997).

In conclusion, the seasonal water use of apple is better evaluated with stable isotope discrimination integrating seasonal variation, rather than with the use of whole canopy gas exchange measurements that measure WUE for brief periods of time. $\Delta^{13} \mathrm{C}$ was negatively correlated with SWUE for six growing seasons, indicating that $\Delta^{13} \mathrm{C}$ was an accurate measurement of apple WUE. Furthermore, $\Delta^{13} \mathrm{C}$ analysis indicated that the PF irrigated treatment had the greatest $\Delta^{13} \mathrm{C}$ and so the lowest WUE compared with the control nonirrigated treatment at LAI from 4 to 6 , which corroborated previous studies (Glenn et al., 2003). The reduced WUE of the PF irrigated treatment compared with the control non-irrigated treatment is likely due to increased $g_{\mathrm{S}}$ from lower canopy temperature and increased canopy $P A R$ diffusion that drove increased A (Glenn, 2009). $\Delta^{13} \mathrm{C}$ increased and WUE decreased with LAI due to internal shading of the canopy. $\delta^{18} \mathrm{O}$ was an indicator of seasonal water use over six growing seasons due to its high correlation with ETo, but $\delta^{18} \mathrm{O}$ response was unaffected by the PF treatments. In 'Empire' apple, A can be increased with PF and irrigation treatments, but at the cost of decreased WUE, which fits with the traditional compromise between photosynthesis and transpiration (Jones, 1976; Raschke, 1976).

\section{Literature Cited}

Bacon, M.A. 2004. Water use efficiency in plant biology, p. 1-22. In: M.A. Bacon (ed.). Water use efficiency in plant biology. CRC Press, Boca Raton, FL.

Barbour, M.M. and G.D. Farquhar. 2000. Relative humidity- and ABA-induced variation in carbon and oxygen isotope rations of cotton leaves. Plant Cell Environ. 23:473-485.

Barbour, M.M., J.S. Roden, G.D. Farquhar, and J.R. Ehleringer. 2004. Expressing leaf water and cellulose oxygen isotope rations as enrichment above source water reveals evidence of a Péclet effect. Oecologia 138:426-435.

Beer, C., M. Reichstein, P. Ciais, G.D. Farquhar, and D. Papale. 2007. Mean annual GPP of Europe derived from its water balance. Geophys. Res. Lett. 34:L05401, doi: 10.1029/2006GL029006. 
Blum, A. 2005. Drought resistance, water-use efficiency, and yield potential: Are they compatible, dissonant, or mutually exclusive? Austral. J. Agr. Res. 56:1159-1168.

Bongi, G., A. Palliotti, P. Rocchi, and G. Roselli. 1994. Evaluation of WUE in peach grafted on different interspecific hybrid rootstocks. Plant Physiol. Biochem. 32:149-157.

Campbell, G.S. and J.M. Norman. 1998. An introduction to environmental biophysics. 2nd ed. Springer-Verlag, New York.

Caspari, H.W., S. Neal, and P. Alspach. 2004. Partial rootzone drying: A new deficit irrigation strategy for apple? Acta Hort. 646:93-100.

Cohen, S. and A. Naor. 2002. The effect of three rootstocks on water use, canopy conductance and hydraulic parameters of apple trees and predicting canopy from hydraulic conductance. Plant Cell Environ. 25:17-28

Davies, W.J., M.A. Bacon, D.S. Thompson, W. Sobeih, and L. Gonzales-Rodriguez. 2000. Regulation of leaf and fruit growth in plants growing in drying soil: Exploitation of the plants' chemical signaling system and hydraulic architecture to increase the efficiency of water use in agriculture. J. Expt. Bot. 51:1617-1626.

Farquhar, G.D. and R.A. Richards. 1984. Isotopic composition of plant carbon correlates with water-use efficiency of wheat genotypes. Aust. J. Plant Physiol. 11:539-552.

Farquhar, G.D., J.R. Ehleringer, and K.T. Hubick. 1989. Carbon isotope discrimination and photosynthesis. Annu. Rev. Plant Physiol. Mol. Biol. 40:503-537.

Farquhar, G.D., L.A. Cernusak, and B. Barnes. 2007. Heavy water fractionation during transpiration. Plant Physiol. 143:11-18.

Flore, J.A., J.W. Moon, and A.N. Lakso. 1985. The effect of water stress and vapor pressure gradient on stomatal conductance, water use efficiency, and photosynthesis of fruit crops. Acta Hort. 171:207218.

Francey, U.J., P.P. Tans, C.E. Allison, I.G. Enting, J.W.C. White, and M. Troller. 1995. Changes in oceanic and terrestrial carbon uptake since 1982. Nature 373:326-330.

Garcia, R.L., J.M. Norman, and D.K. McDermitt. 1990. 9. Measurements of canopy gas exchange using an open chamber system. Remote Sens. Rev. 5:141-162.

Glenn, D.M. 1995. Irrigation scheduling, p. 161-168. In: H. Hogmire (ed.). Mid-Atlantic orchard monitoring guide. Northeast Regional Agricultural Engineering Service, Ithaca, NY.

Glenn, D.M. 1999. Analysis of trickle and pulse microsprinkler irrigation of processing apples. J. Tree Fruit Production 2:11-17.

Glenn, D.M. 2009. Particle film mechanisms of action that reduce the effect of environmental stress in 'Empire' apple. J. Amer. Soc. Hort. Sci. 134:1-8.

Glenn, D.M., E. Erez, G.J. Puterka, and P. Gundrum. 2003. Particle films affect carbon assimilation and yield in 'Empire' apple. J. Amer. Soc. Hort. Sci. 128:356-362.

Glenn, D.M. and G.J. Puterka. 2007. The use of plastic films and sprayable particle films to increase light penetration in apple canopies and improve apple color and weight. HortScience 42:9196.

Glenn, D.M., R. Scorza, and C. Bassett. 2000. Physiological and morphological traits associated with increased water use efficiency in the narrow-leaf peach. HortScience 35:1241-1243.

Glenn, D.M., R. Scorza, and W.R. Okie. 2006. Genetic and environmental effects on water use efficiency in peach. J. Amer. Soc. Hort. Sci. 131:290-294.

Goldhammer, D.A., M. Salinas, C. Crisosto, K.R. Day, M. Soler, and A. Moriana. 2002. Effects of regulated irrigation and partial root zone drying on late harvest peach tree performance. Acta Hort. 592:343-350.

Green, S.R., K.G. McNaughton, D.H. Greer, and D.J. McLeod. 1995. Measurement of the increased $P A R$ and net all-wave radiation absorption by an apple tree caused by applying a reflective ground covering. Agr. For. Meteorol. 76:163-183.

Impa, S.M., S. Nadaradjan, P. Boominathan, G. Shashidhar, H. Bindumadhava, and M.S. Sheshshayee. 2005. Carbon isotope dis- crimination accurately reflects variability in WUE measured at a whole plant level in rice. Crop Sci. 45:2517-2522.

Jones, H. 2004. What is water use efficiency? p. 27-40. In: M.A. Bacon (ed.). Water use efficiency in plant biology. CRC Press, Boca Raton, FL.

Jones, H. 1992. Plants and microclimate: A quantitative approach to environmental plant physiology, 2nd ed. Cambridge University Press, Cambridge, UK

Jones, H.G. 1976. Crop characteristics and the ratio between assimilation and transpiration. J. Appl. Ecol. 13:605-622.

Leib, B.G., H.W. Caspari, C.A. Redulla, P.K. Andrews, and J.J. Jabro. 2006. Partial rootzone drying and deficit irrigation of 'Fuji' apples in a semi-arid climate. Irrig. Sci. 24:85-99.

LeRoux, X., T. Bariac, H. Sioquet, B. Genty, C. Piel, A. Mariotti, C. Girardin, and P. Richard. 2001. Spatial distribution of leaf water-use efficiency and carbon isotope discrimination within an isolated tree crown. Plant Cell Environ. 24:1021-1032.

Li, F., S. Cohen, A. Naor, K. Shaozong, and A. Erez. 2002. Studies of canopy structure and water use of apple trees on three rootstocks. Agr. Water Mgt. 55:1-14.

Loveys, B.R., M. Stoll, and W.J. Davies. 2004. Physiological approaches to enhance water use efficiency in agriculture: Exploiting plant signaling in novel irrigation practice, p. 113-141. In: M.A. Bacon (ed.). Water use efficiency in plant biology. Blackwell, Oxford, UK.

Masle, J., S.R. Gilmour, and G.D. Farquhar. 2005. The ERECTA gene regulates plant transpiration efficiency in Arabidopsis. Nature 436:866-870.

Morison, J.I.L., N.R. Baker, P.M. Mullineaux, and W.J. Davies. 2008. Improving water use in crop production. Phil. Trans. Royal Soc. London. Ser. B. Biol. Sci. 363:639-658.

Parkinson, K.J., W. Day, and J.E. Leach. 1980. A portable system for measuring the photosynthesis and transpiration of graminaceous leaves. J. Expt. Bot. 31:1441-1453.

Raschke, K. 1976. How stomata resolve the dilemma of opposing priorities. Phil. Trans. Royal Soc. London. Ser. B. Biol. Sci. 273: 551-560.

Robinson, T.L. and A.N. Lakso. 1991. Bases of yield and production efficiency in apple orchard systems. J. Amer. Soc. Hort. Sci. 116: $188-194$.

Rosati, A., S.G. Metcalf, R.P. Buchner, A.E. Fulton, and B.D. Lampinen. 2007. Effects of kaolin application on light absorption and distribution, radiation use efficiency and photosynthesis of almond and walnut canopies. Ann. Bot. (Lond.) 99:255-263.

Saurer, M., K. Aellen, and R. Siegwolf. 1997. Correlating $\delta^{13} \mathrm{C}$ and $\delta^{18} \mathrm{O}$ in cellulose of trees. Plant Cell Environ. 20:1543-1550.

Sharp, R.I., V. Poroyko, L.G. Hejlek, W.G. Spollen, G.K. Springer, H.J. Bohnert, and H.T. Nguyen. 2004. Root growth maintenance during water deficits: Physiology to functional genomics. J. Expt. Bot. 55:2343-2351.

Sheshshayee, M.S., H. Bindumadhava, R. Ramesh, T.G. Prasad, M.R. Lakshminarayana, and M. Udayakumar. 2005. Oxygen isotope enrichment $\left(\Delta^{18} \mathrm{O}\right)$ as a measure of time-averaged transpiration rate. J. Expt. Bot. 56:3033-3039.

Testi, L., F. Orgaz, and F. Villalobos. 2008. Carbon exchange and water use efficiency of a growing, irrigated olive orchard. Environ. Expt. Bot. 63:168-177.

Wibbe, M.L. and M.M. Blanke. 1995. Effects of defruiting on sourcesink relationship, carbon budget, leaf carbohydrate content and water use efficiency of apple trees. Physiol. Plant. 94:529-533.

Wullschleger, S.D., F.C. Meinzer, and R.A. Vertessy. 1998. A review of whole-plant water use studies in trees. Tree Physiol. 18:499-512. Xiloyannis, C., V. Nuzzo, B. Dichio, G. Celano, and G. Mantanaro. 2000. Characterization of training systems in relation to water use efficiency in apricot and kiwifruit plants. Acta Hort. 537:207-231.

Zegbe, J.A. and M.H. Behboudian. 2008. Plant water status, $\mathrm{CO}_{2}$ assimilation, yield, and fruit quality of 'Pacific Rose ${ }^{\mathrm{TM}}$ ' apple under partial rootzone drying. Adv. Hort. Sci. 22:27-32. 